of the Royal Medical and Chirurgical Society, we believe that he was not absent on a sinule occasion, and this is no small praise to a surgeon in his extensive and laborious practice. But it was after the reading of a paper that he was particularly great. Acting up to his axiom, that the debat 's in the Society constituted its most important and interesting feature, he al ways encouraged discussion. He would wait for a few minutes to see if any fellow was inclined to begin, and if he was disap. pointed in this, after calling attention to some of the more prominent and salient points in the production before them, he would lead the way by giving his own opinions and experience on the subject matter. Few of those who had the pleasure of hearing him will forget with what precision he spoke; how completely he kept ad rem, and how easily he brought his vast experience, and that, too, without preparation, to bear upon the production of the author, whoever it might be. We scarcely recollect a single evening during the two sessions that Sir Benjamin presided in which he did not address the meeting. He seemed not to be at a loss on any subject, and no one could help being astonished, no less at the extent of his acquirements, than at the facility with which they were made available. He was remarkable, also, in keeping the various speakers within bonnds, for whilst he was a staunch friend to discussion to its legi imate extent, he conld not tolerate discursive flights, "To show the stretch of human brain, Mere curi,us pleasure or ingenious pain."

$\mathrm{He}$ encouraged discussion, too, at a time when it was not fashionahle to do so: some of his predecessors in office having almost "burked" it, and some of the members of the governing body having actually meditated a war against the press for publishing the debates of the Society. Rising above all such petty feelings and motives, Sir B. Brodie took the enlarged view of the subject, and contended that a greater publicity of the proceedings of the Society could only add to its reputation and its usefulness. From the period of his presidency may be dated the remarkable prosperity of the Mer ical and Chirurgical Society, and this is mainly attributable, we believe, to the morle in which he fostered and protected discussion. Should the Society fall into a useless and silent meeting-place, it will be from the future presidents not following in the foot. steps of the distinguished subject of our sketch

In the pages of ThE LANCET, and there unly, are preserved a great number of facts and opinions arising out of the expe. rience of Sir Benjamin, and communicated by bim to the So ciety, with which otherwise it is more than probable the great body of the profession would not have been made acquainted. We take some credit to ourselves for having preserved these memorials in the durahle form given to them by the exertions of an independent medical press.

In his address at the close of each sfssion Sir B. Brodie was particularly happy, and as these addresses at the time were published in THE LANCET, we need do no more than call attention to them. On his retirement as President of the Society, we do not believe there was a single fellow who did not regard it as a personal loss and misfortune.

One evidence of the general consent with which Sir Benj. Brodie was regarded as the head of the profession, may be found in the frequency with which his advice was sought by the different Gover, ments of the day in any matter of diffi culty connected with Medicine. One of the latest instances of this related to the Smethurst case, when, after consulting the highest ohstetrical opinion, Sir Benjamin, as is well known, reversed the decision of the judge and jury.

For a long series of years he fulfilled the duties of Examiner of the College of Surgeons and member of the Council, having only retired from the examinership a few years sincc. He hins also tilled the offices of Vice-President and President of the College. He was an ex-offcio member of the Board of Examiners as Serjeant. Surgeon, but at his wish the Council petitioned her Majesty to abrogate this privilege, and on his retirement it was abolished. At the Royal Society he was a constant worker as nember of the Council, and formerly as member of the Physiological Committee. He was the surgical attendant of three sovereigns, from George IV. to Victoria inclusive, and no man charged him that his duties to rich or poor had been ill-performed. When we reflect upon all these variuus works, we must confess the author was a yreat man in our profession, and capable of greitness in any walk of life.

When the passing of the Merlical lieform Act, for the first time in the history of Medicine, gave a legal head to the entire medical profession of the three kingdoms, and indeed of the whole British empire, in the person of the presilent of the General Council of Medical Education and Registration, Sir Benjamin was elected to fill this dignified position, with the unanimous approval of the profession. It was thought that at this time the Government might have taken the opportunity of doing just honour to the medical profession, and of recog. nizing the distinguished position of Sir Benjamin Brodie. A report arose that he woull be raised to the peerage, as Baron Betchworth of Betchworth ; but Lord Derby's Ministry made baste to give official contradiction to the welcome rumour. A triend received, shortly after this time, a letter from Sir Benjamin, in which, with his usual and unaffected modesty, he expressed the satisfaction he felt at the want of confirmation which the report had received. There can be little doubt that if Lord Palmerston's plan of creating life peerages had not been defeated, Sir Beujamin Brodie wonld have died a peer. As it is, the peerage is an bonour still, as far as precedent is concerned, beyond the reach of the medical profession. So far as wealth, position, and national esteem can go, there can be no question that Sir Benjamin Brodie would have graced and honoured the peerage as much as any clerical or legal creation of modern times. We believe Sir Astley Cooper was once near receiving a coronet; and we have been assured by a relative of Sir Richard Croft that he was pro. mised a peerage by George IV. if all had gone well with the Princess Charlotte. We can only hope, for the honour of the profession, that Sir Charles Locock, now almost the only medical baronet, and in every way holding a higher position than -ir Richard Croft could ever have aspired to, may reach the eminence hitherto unattained by any medical man.

\section{LETTER FROM MR. CHARLES HAWKINS.}

\section{To the Editor of THE LANCET.}

Sir-It is with much regret that $I$ announce to you the death of Sir Benjamin Brodie. His most valuable life was brought to a close last night, with as little suffering as was possible under the circumstances of the case.

Anything that concerned the welfare and honour of the medical profession interested him to the last. A few days before his death, when speaking of the probable speedy termination of his life, he said to me-" If any of my medical friends should speak to you of me, remember me kindly to them."

Savile-row, Oct.22nd, 1862. I am, Sir, \&c.,

\section{A TOOTH DRIVEN INTO THE JAW.}

\section{To the Editor of THE LANCET.}

SIR,-If you deem the following case of sufficient interest to entitle it to be recorded in your columns, I shall be glad if you will kindly insert it.

W. T-_-, aged fourteen, whilst out ploughing on July $28 \mathrm{th}$, 1862 , in the capacity of waggoner's lad, was kicked in the face by one of the horses composing the team, and received the following injury :-A wound of about two inches in length, passing olliquely through the right cheek and lower lip into the mouth. The teeth, with the exception of the right upper canine, which had disaypeared from view, had escaped injury. My first impression was that the crown of this tooth had been broken off. but on further examination it was found to be completely buried within its alveolns, the apex of it only being visible on separating the gum. Finding, after having extracted it with a pair of Clendon's stump forceps, that it was to all appearance uninjured, I at once replaced it in its natural position, desiring he boy to live on fluids for a few days, or until the tooth had become sufficiently firm to allow of its being used in mastiation The wound, the edges of which were brought together by sutures and adhesive plaster, healed in a few days, and at the expiration of a week from the receipt of the injury, the dislocated tooth had become quite firmly fixed on a level with the neighbouring teeth.

There appear to me to be two points of interest in this otherwise simpl. case. viz.:- That the tooth should have been so completely driven into tle $j$, $w$ like a vail without either itself or neighbours sustaining any injury; to be accounted for, perhaps, by the fact of the canine treth being frequently more prominent than the o: hers, am which I found, by examining the fellow-tooth on the opposite side, to be the case in this boy. Also that the tooth should have been so speedily and firnly reestablisherl in its yatural position after having been entirely removed from its alveolus- a circumstance which had never previously come under my notice, although I was aware that it was not a very rare occurrence. - Yours, \&c.

Sancon, Supt. 1562. 